\title{
Agglomeration in Tourism: The Case of SEZs in Regional Development Goals
}

\author{
${ }^{1}$ FITRI RAHMAFITRIA, ${ }^{2}$ HERU PURBOYO, ${ }^{3}$ ARIEF ROSYIDIE \\ 1,3 Bandung Institute of Technology, Jl. Ganesha no 10, Bandung, Indonesia, \\ 2Indonesia University of Education, Jl. Setiabudi no. 229, Bandung, Indonesia \\ email: 1, rahmafitria@upi.edu; 2 purboyohp@gmail.com; 3ariefrosyidie@yahoo.com
}

\begin{abstract}
The Special Economic Zones (SEZs) is one of the tourism agglomeration models whose effectiveness in meeting development goals needs to be analyzed. Tourism agglomeration policies that are not in line with the national development goals will cause inequality, especially in the welfare of the local community. The aim of this study is to analyses the effectiveness of SEZ policies in achieving regional development goals by comparing the community prosperity level with the goals of tourism development. The study is conducted by employing the meta-analysis method and uses secondary data of economic study from the West Nusa Tenggara Province which compares the National Development Index (HDI) with the regional tourism development targets. There is a quite large gap between the quality of education of the local community and the standard of human resource (HR) requirements specified in the SEZs. Management of tourism agglomeration must be carried out with a sustainable development approach, namely by integrating tourism development strategies into regional development.
\end{abstract}

Keywords: tourism agglomeration, regional development, government role

\section{Introduction}

Currently, the cluster as part of agglomeration is a concept widely employed in regional development. Agglomeration is considered as a necessity in urban and regional developments since its impact on increased economic growth has been widely proven (Cohen and Paul, 2009). Theoretically, agglomeration will have an impact on the company's economy both internally and externally. Internally, agglomeration can increase the cost efficiency for the company through the effects of economies of scale and scope and economies of complexity (Parr, 2002). Due to its various advantages, the agglomeration has become a preferred model of business development to achieve economic efficiency and an alternative in regional development. However, on another side, agglomeration also can produce a backwash effect where the rapid growth of industrial groups causes a monopoly, thus, shutting down the development of other areas around it (Parr, 2002; Cohen and Paul, 2009). Moreover, the strong economic growth in the core region will cause migration, thereby increasing the labour competition and reducing the ability to protect local labour (Chiang, 2018; Martin and Ottavianno, 2001).

The positive impact of agglomeration on regional economic growth has made the Indonesian government issue Law No. 39 of 2009 concerning Special Economic Zones (SEZs). SEZ is an industrial area that is given special facilities, infrastructure and incentives, tax breaks, permits, immigration, and labour affairs. There are seven SEZs, and one of them is the tourism sector. The purpose of establishing tourism in SEZ is to attract investors through the ease of investment to spur the development of tourism. This model is part of the agglomeration approach initiated through government policy.

Empirically, tourism as one of the industry sectors that are seeded in the SEZ is closely linked to the concept of agglomeration. Agglomeration of the tourism industry is, in fact, made the basis in the development of tourist areas, both at regional and local scales. The clustering model in tourism is part of an agglomeration that groups tourist

Received: 2019-07-14, Revised: 2019-08-05, Accepted: 2019-12-25

Print ISSN: 0215-8175; Online ISSN: 2303-2499. DOI: https://doi.org/10.29313/mimbar.v35i2.4871

Accredited Sinta 2 based on the decree No.10/E/KPT/2019 until 2024. Indexed by DOAJ, Sinta, Garuda, Crossreff, Dimensions 
areas based on the uniqueness and prominent qualities of a region (Urtasun \& Gutiérrez, 2006; Benner, 2017; Liu et al, 2018). In general, tourist areas are grouped based on the most dominant characteristics of the region, such as geographical locations; hence, tourist destinations have been classified into, among others, mountain-based destinations, beach resorts, culture-based destinations, and others (Gunn, 2002). The relationship between geographical factors and regional landscape characteristics greatly influences the type of tourism agglomeration formed (Kachniewska, 2013) and the development of the types of industries (hotels, restaurants, travel agents, and others). The clustering model in the tourism sector will resemble the geographical pattern of that of mining industries, but slightly different from the pattern of service industries (Benner, 2017; Liu et al, 2018).

Tourist areas that rely heavily on the strengths and uniqueness of natural resources will be greatly influenced by geographical factors. In the theory of agglomeration, there are concepts of backward linkages and forward linkages, in which the former is concerned with access to raw material sources and the latter access to market (Parr, 2002). These two internal components of agglomeration will become a basis of consideration by the industry in choosing a location. However, when the tourism industry relies heavily on the uniqueness of nature which is located remotely far and is characterized by inseparability (should be enjoyed at its original location), the industry will not be able to efficiently manage the distance in relation to the market (Yang, Shi, \& Zhong, 2018). In addition, the construction of an industrial centre at the core location of the natural attraction will be a threat to natural resources and ultimately reduce the location's attractiveness. This characteristic of tourism makes tourism development highly dependent on government policies rather than market mechanisms in building industrial agglomerations and presents a challenge in building the concept of tourism agglomeration.

Another challenge in building the concept of tourism agglomeration is the impact of economic externalities on the welfare of local communities. Rapid economic growth as an effect of agglomeration will have an impact on externalities, which in some theories are associated with specialization, urbanization, and activity-complex economies
(Parr, 2002). The impact of externalities, according to Helmsing (2001), is high inequality with the surrounding area which is not intervened with the easiness and does not receive the efficiency effect of agglomeration (Helmsing, 2001; Karlsson \& Gråsjö, 2018). This backwash effect will worsen the distortion of development in other regions. The tourism SEZ model, when built with an exclusive concept, will hamper the economic growth of the surrounding areas, making the local community increasingly lagging, especially if the facilities and access are only focused on the ease of investment by external parties. The quality of tourism infrastructure that often uses international standards also creates a large knowledge gap with local communities, decreasing the impact of agglomeration on the absorption of local labour (Urtasun \& Gutiérrez, 2006; Wildan, Sukardi, and Zulfikar, 2016).

Anomalies in tourism agglomeration cannot be addressed by neoclassical agglomeration theory. Minimizing production costs through perfect market competition will not be able to build a nature-based model of tourism agglomeration because the long and difficult distances will increase the costs of potential sources of labour. The theory, moreover, is insufficient to address the concern with agglomeration's influence on people's welfare. The neo-classical theory focuses more on the internal benefits of agglomeration and has not been able to answer the challenges of externalities (Cohen and Paul, 2009). In terms of externalities, geographical proximity will facilitate the transmission of ideas which will make the industry grow. The debate has arisen on which force is the most influential on the transfer of knowledge, either at local monopolies or local competition (Martin and Ottavianno, 2001). In the context of tourism, strengthening local competition must be prioritized as an effort to protect regional assets (Tresiana and Duadji, 2018), which stands in contrast to the new economic geography theory that emphasizes the aspect of the network (linkage) as the main factor that drives the occurrence of agglomeration (Cohen and Paul, 2009; Martin and Ottavianno, 2001). At present, the economic development paradigm has undergone a shift in its focus from the indicators of economic growth to the indicators of the quality of community and environment (MacGillivray, 2017; Fauzi \& Oxtavianus, 2014). The concept of limitation of development arises from a model of 
FITRI RAHMAFITRIA, et al. Agglomeration in Tourism: The Case of SEZs in Regional Development Goals...

sustainable development, where the existence of natural resources is very dependent on human's wise on the use of the resources (Urtasun \& Gutiérrez, 2006).

The explanation above shows that in encouraging tourism agglomeration in nature-based areas, the role of the government as a regulator becomes very important. Without the support of accessibility and ease of investment, the industry will only act by economic interest without any concern for developing tourism. However, the government must also consider the impact of this agglomeration incentive on the preservation of natural areas and the welfare of local communities, which both are the goals of regional development.

Empirically, the agglomeration model in the tourism industry has been widely implemented, but its theoretical discussion is still scarce, especially in terms of the effectiveness of the agglomeration policy in relation to regional development goals. The gap shows the need to explore approaches to implement agglomeration policies in tourism. This paper argues for cluster policy (SEZs) in tourism development, especially in the context of the integration of tourism development with regional development strategies.

The description above shows that tourism development strategies that are not integrated with regional development are often ineffective in dealing with problems in the regions. This paper criticizes the neoclassical agglomeration theory which depends on the market mechanism scheme and ignores the impact of externalities. Then, agglomeration in tourism should involve government intervention to ensure economic development for the local community by integrating development goals into tourism planning. Through a case study, this research will analyze the effectiveness of SEZ policies as a tourism agglomeration in regional development goals. This paper argues that the government's support for the formation of SEZs through the ease of investment and accessibility to tourist destinations must be accompanied by protection policies that focus on environmental sustainability and natural resources as well as improving community welfare (Figure 1). Partial tourism policies will result in artificial development which only works to increase the number of tourists (quantity), but does not have a positive impact on the regional economy. The aim of this paper is to verify that the need for integration of regional development into tourism planning is crucial, especially in achieving national development goals. The theory proposed in this paper is drawn from the dynamic externality approach which requires a policy intervention so that the companies in an SEZ can participate in sustaining the tourism attractions and preventing migration of human resources to protect the local labour.

\section{Research Methodology}

The study was conducted in Mandalika Regency, West Nusa Tenggara Province, as one of the tourism SEZs in Indonesia, which has been operating since 2017. The study was conducted employing the meta-analysis method and using secondary data in the form of reports of the West Nusa Tenggara Province

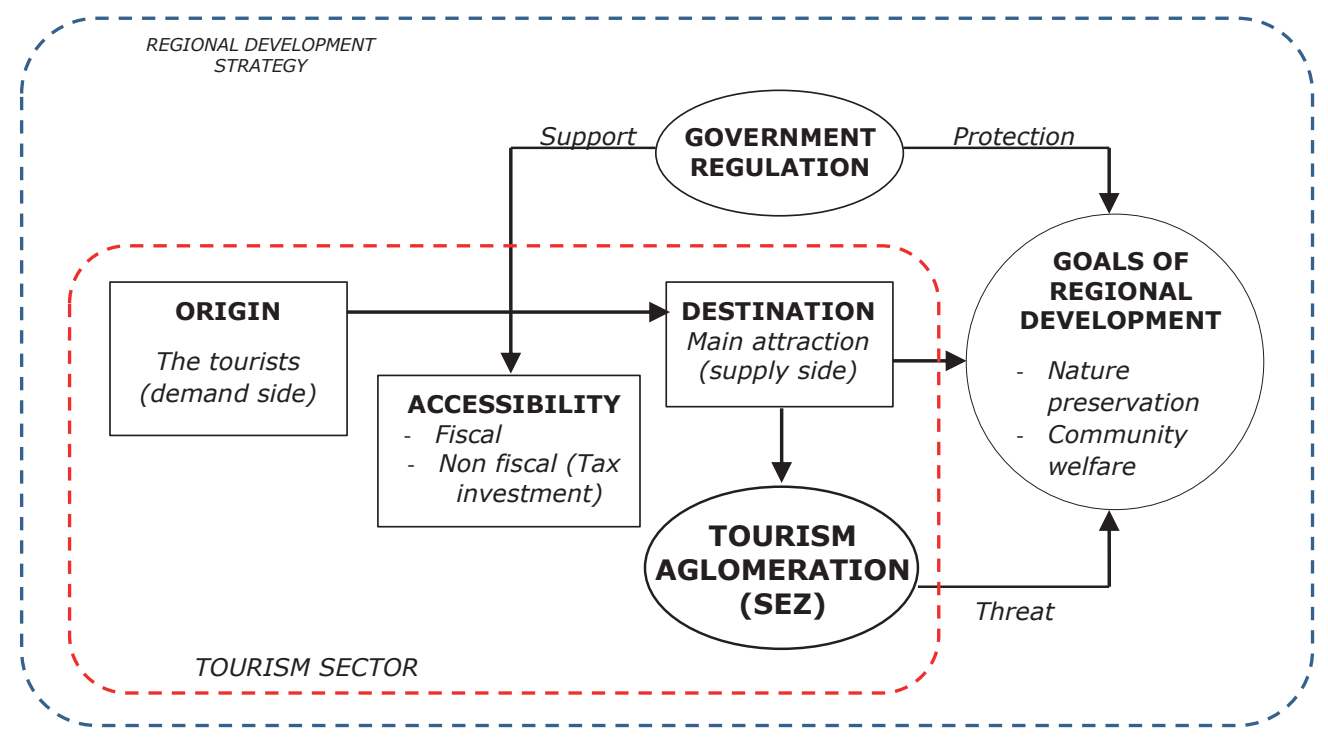

Figure 1. The Concept of Sustainable Tourism Agglomeration 
Regional Economic Study and other literature.

The study was carried out in the following stages: (1) explaining the potential (internal) and government's (external) support in realizing tourism agglomeration in SEZ Mandalika; and (2) analyzing the strengths and weaknesses of the SEZ Mandalika policy as an agglomeration policy that drives the growth of tourism clusters based on regional development indicators. From this analysis, the conception of tourism agglomeration will be illustrated through the integration of the tourism sector with regional development. This study was conducted by comparing SEZ incentive policies provided by the government with regional development achievements. The indicators for the achievement of regional development goals used here are the HDI and labour absorption. The findings will be used as a reference in drafting the concept of integration of the tourism sector into regional development.

\section{Results and Discussion}

\section{Tourism potentials and government support in SEZ Mandalika}

SEZ Mandalika is located in the south of Lombok Island with an area of $1,035.67$ ha under the administration of Central Lombok Regency. Geographically, Central Lombok Regency is located between $116^{\circ} 05^{\prime}$ to $116^{\circ} 24^{\prime}$ East Longitude and $8^{\circ} 24^{\prime}$ to $8^{\circ} 57^{\prime}$ South Latitude with the northern part bordering Mount Rinjani, the southern part is the Indonesian Ocean, the western part is the Regency of West Lombok, and the eastern part is East Lombok Regency. The population is around 860,209 with a low density of 712 people $/ \mathrm{km} 2$. Most of the areas are utilized for agriculture with a farmer as a dominant livelihood of the population ( $72 \%$ ).

The region was designated as an SEZ due to its marine tourism potentials such as
Kuta Beach, Seger Beach, and Tanjung Aan Beach, and its cultural tourism potential in the form of traditional villages. There are two well-known traditional villages, namely the Adat Sade Village and the Ende Traditional Village which occupied by the Sasak people who are native to Lombok Island.

The designation of some areas of Central Lombok Regency as tourism SEZs is inseparable from the increasingly developed tourism in Nusa Tenggara Barat (henceforth, NTB) Province. This increased development is marked by the increasing number of foreign and domestic tourist visits from 2009 to 2016 (Table 1). Compared to 2016, the number of tourists grew up to $27.61 \%$ in 2017 , especially for foreign tourists. This increase was driven by the addition of direct international flights.

NTB's economy for $18.94 \%$. This figure made tourism the biggest contributor to NTB's economy in 2017 after the agriculture and mining sectors. The target of NTB's tourism development is 4 million foreign tourists in 2018.

NTB's tourism growth is also marked by the increased investment in hotels, restaurants, recreation centres, and other tourism services and businesses by $22 \%$ in 2017. According to NTB's economic reports compiled by Bank of Indonesia, the tourism sector contributed to

The government's support for NTB's tourism was realized in the Provincial Road Improvement and Maintenance (PRIM) project from 2013 to 2015, with funding from Australia-Indonesia infrastructure grants. The construction of the International Airport Zainudin Abdul Madjid in 2006 and the PRIM project were expected to increase accessibility to tourist destinations and encourage regional tourism development. Furthermore, the high tourism potential in NTB has encouraged the government to issue Regulation No. 52 of 2014 concerning Mandalika as a Special

Table 1

The Number of Foreign and Domestic Tourist Visits to NTB (2009-2016)

\begin{tabular}{|c|c|c|c|c|c|c|c|c|}
\hline \multirow{3}{*}{$\begin{array}{l}\text { Year } \\
\text { Number of } \\
\text { Tourists }\end{array}$} & \multicolumn{8}{|c|}{ Foreign Tourists } \\
\hline & 2009 & 2010 & 2011 & 2012 & 2013 & 2014 & 2015 & 2016 \\
\hline & 232,525 & 282,161 & 364,196 & 471,706 & 565,944 & 752,306 & $1,061,292$ & $1,404,328$ \\
\hline & \multicolumn{8}{|c|}{ Domestic Tourists } \\
\hline $\begin{array}{l}\text { Number of } \\
\text { Tourists }\end{array}$ & 386,845 & 443,227 & 522,684 & 691,436 & 791,658 & 876,816 & $1,149,235$ & $1,690,109$ \\
\hline TOTAL & 619,370 & 725,388 & 886,880 & $1,163,142$ & $1,357,602$ & $1,629,122$ & $2,210,527$ & $3,094,437$ \\
\hline
\end{tabular}


FITRI RAHMAFITRIA, et al. Agglomeration in Tourism: The Case of SEZs in Regional Development Goals...

Economic Zone (SEZ) with several special facilities that attract investors to invest. The special facilities are manifested in fiscal and non-fiscal policies targeted at investors (such as tax relief and retribution), acquisition of land rights, security guarantees, and others. SEZ policies and the designation of Lombok as one of the leading tourist destinations in Indonesia have encouraged increased investment in the tourism sector. The government further encouraged tourism destination development programs in NTB through the rehabilitation of facilities in public tourist destinations and waste management by allocating the Regional Revenue and Expenditure Budget of 14 billion rupiahs for constructing 36 tourism destinations.

The great support from the government for tourism development in NTB aims to increase the country's foreign exchange and encourage regional economic development. The final target is the achievement of public welfare and equal opportunities for all people to enjoy the beauty of Indonesian nature and culture.

It is then necessary to analyze the strong support given by the government in terms of its effectiveness for the achievement and realization of development goals. Based on NTB regional economic studies reported by the Bank of Indonesia (2014), the role of the tourism sector is measured based on the number of tourist visits, hotel growth, and tourism industry. The number of tourist visits continued to increase by $27 \%$, followed by the number of hotels reaching 331, which was indicating success in terms of achievement targets.

\section{SEZ Mandalikaas tourism cluster in NTB Province}

In 2017, the government urged for the immediate implementation of SEZ Mandalika. Previously in July 2014, the government had disbursed 14 billion rupiahs for infrastructure development. But, the policy had to face a problem with land acquisition. SEZ is a development policy implemented by the Indonesian government towards integrated tourism, combining nature-based tourism, cultural tourism, and artificial tourism that is focused on developing conventions (Incentive Conference Event Meeting/MICE). SEZ Mandalika is located in the southern part of Lombok Island, with an area of $1,035.67 \mathrm{ha}$. The main tourist attraction in this region is marine tourism with beaches and interesting underwater ecosystems. At present, the government is authorizing the Indonesia Tourism Development Corporation (ITDC), a private company that has succes sfully developed Nusa Dua Bali, to develop Mandalika. The SEZ provides an overview of government incentives directed at the ease of investment and encourages the formation of a tourism agglomeration model. The target is to reach 2 million tourists in 2019, and currently, SEZ Mandalika is the most attractive island for investors and is expected to become a world-class tourist destination.

In general, the purpose of developing SEZs is to increase investment, employment, and foreign exchange through international trade; to utilize local resources and value of product competitiveness, and quality of human resources through technology transfer. This is also mentioned by Lajara et al (2016) that tourism agglomeration will cause some positive impact to the growth of regional economy.

Indonesian government's support for the development of SEZ Mandalika takes the forms of physical and non-physical policies. The policies aim at easy accessibility for investors and tourists. Physical policies are directed at regional infrastructure development through the development of Lombok International Airport, Batu Jai Praya clean water installations, Lembar Harbor, Penunjak-Kuta national strategic roads (for $18 \mathrm{~km}$ ), Kuta $150 \mathrm{Kv}$ substation, and Mujur Dam (Bank of Indonesia, 2014). Specifically, for non-physical policies, the fiscal and nonfiscal policies are the government's incentives for the easy accessibility of tourists and investors. The non-physical facilities of SEZ Mandalika are:

Fiscal Facilities, Every business taxpayer in the SEZs is given income tax facilities, additional income tax facilities according to zone characteristics, reduction of land and building tax, customs and custom duty facilities within SEZs and other regions, incentives in the form of exemption or relief of regional taxes and retribution

Non-Fiscal Facilities, The ease of obtaining land rights in accordance with laws and regulations and the ease and relief in business licensing, business activities, industry, trade, port, and immigration for foreign business actors, as well as security facilities in accordance with laws and 
regulations

The great support from the government for the development of SEZ Mandalika has made the area attractive to investors. However, the support is not sufficient to accelerate the completion of the development projects in this region. Based on previous reports and research results, some of the obstacles include 1) the masterplan of strategic location development is not managed by ITDC but leased to investors dominantly from foreign countries, 2) dominance of foreign investors playing the role of developers, 3 ) land acquisition that is hindered by regional autonomy.

\section{An analysis of tourism SEZ policy}

SEZ Mandalika has been successfully proven as an effective policy supporting the tourism industry agglomeration. The massive infrastructure development in this zone has attracted most investors, according to Bank of Indonesia (2018), and becomes the highest of the four tourism SEZs in Indonesia. Several of the committed investors are, among others, Rajawali Group (hotels dan villas), PT Gobel International (clean water and waste management), PT Global Land Development (theme park and technopark), and MNC Group (F1-circuit as well as Plenary hall). To measure the effectiveness of the SEZ Mandalika policy, an analysis of the target achievements in conjunction with the regional development targets is necessary. The analysis is detailed in the following parts. Thus, this kind of agglomeration will be potentially lead to externalities and cause higher costs when the degree off agglomeration is nether (Lajara et al, 2016: Segarra-Oña et al, 2012).

\section{Comparison to HDI index}

The Human Development Index (HDI) is an indicator of a region's development, consisting of economic, social, information and technology, public infrastructure and facilities, and living environment indicators. Over the past 10 years, NTB's HDI was among the lowest in Indonesia. Based on data from https://ntb.bps.go.id, NTB ranked 29th out of a total of 34 provinces in Indonesia. Based on HDI scores for NTB province, from the 10 existing regencies, Central Lombok Regency, where SEZ Mandalika is located, had the lowest IPM sequence (Table 2 )

Table 2 shows that the designation of Mandalika as a tourism SEZ is primarily based on natural beauty and potential as the main capital of tourism development. Destination readiness, both socially and economically, is not taken into consideration, necessitating the government's intervention in the form of policies and development of regional public infrastructure. The government plays a significant role in encouraging the formation of tourism industry clusters in this region.

However, the large gap between the SEZ development targets and the low HDI score will result in a backwash effect, causing the local and surrounding areas to be increasingly lagging due to their inability to be involved in and contribute to the development of SEZ Mandalika. SEZ Mandalika will become an exclusive enclave in Central Lombok Regency. This is in line with Yang, Shi, \& Zhong (2018) and Sodik and Iskandar's (2007) research reporting that agglomeration had a positive influence on economic growth and a negative influence on poverty and HDI levels. Therefore, SEZ Mandalika needs urgent tourism strategies' transformation and

Table 2

\section{Comparison between KSPD (Regional Tourism Strategic Areas)} and HDI in NTB (2017)

\begin{tabular}{|c|c|c|c|c|}
\hline No & Tourism Strategic Area & City/Regency & HDI & HDI Graph of NTB \\
\hline 1 & Mataram & Mataram City & 77.84 & 77.84 \\
\hline 2 & Bima & Bima City & 74.36 & 74.36 \\
\hline 3 & Pototano Maluk Batu Hijau & Sumbawa Barat & 70.08 & 70.08 \\
\hline 4 & Hu'u & Dompu & 66.33 & 66.33 \\
\hline 5 & Alasutan, Samota & Sumbawa & 65.84 & 65.84 \\
\hline 6 & Wawo roda & Bima Regency & 65.01 & 65.01 \\
\hline 7 & Rasimas Sembilun & Lombok Timur & 64.37 & 64.36 \\
\hline 8 & Senggigi & Lombok Barat & 66.37 & 66.37 \\
\hline 9 & Mandalika & Lombok Tengah & 64.36 & 64.36 \\
\hline
\end{tabular}

Source: Adapted from various sources 
FITRI RAHMAFITRIA, et al. Agglomeration in Tourism: The Case of SEZs in Regional Development Goals...

upgrading to improve its regional economic.

\section{Job opportunities}

The existence of industrial agglomeration is expected to be able to create greater employment opportunities and to affect the quality of human resources, both directly and indirectly. Based on the Regional Economic Review prepared by Bank of Indonesia (2018), the contribution of labour to the economy in eastern Indonesia in 2017 was generally still low and negative, creating a considerable gap with other regions. The quality and quantity of labour were still low due to low education levels and the HDI that was below the national average. The number of high school graduates was also still low, especially when compared to Bali. From the results of analysis specifically for the NTB region, the quantity of labour was quite high, except that the quality was still low, especially in terms of hard skills, creativity, and communication skills which form the basic competence of operational workers in the tourism industry.

In addition, from the aspect of Labour Mobility Cost (LMC), higher costs will be incurred for workers from Bali and Nusa Tenggara to work in other areas, reaching up to 14.95 times of their income. This could cause problems given that workers from other provinces have lower costs of entering and working in NTB. Chiang (2018), Martin and Ottavianno (2001) have mentioned that the strong economic growth in the core region will cause migration, thereby increasing the competition in labour and reducing the ability to protect local labour. Since the gap of NTB's HDI level with the qualification standard of tourism human resources is quite high, therefore, externalities impact will potentially occur.

The existing data on labour also indicate the quality of NTB tourism human resources. In terms of position, $38.24 \%$ of the workers at the operational level had qualifications below the standard, while approximately $29.53 \%$ of the supervisors and management levels' qualifications were below the standard. Regarding academic qualification, $48.71 \%$ of the tourism workforce did not have an adequate qualification. Bank of Indonesia also projected that labour needs based on economic growth for 2025-2030 in NTB Province will experience a shortage of 20,000-38,000 workers in the tourism sector, particularly at supervisor and operational levels.
The data further show that there was a large employment gap in 2017. Given the operational target of SEZ Mandalika in 2019 of 2 million tourists, this employment gap will pose some problems. SEZs that are prepared as an international level of tourist destinations will require workers with high qualifications; meanwhile, the quality of NTB workers is still low. Labour migration will unavoidably occur to meet the need for 20,000-38,000 workers. This condition will widen the economic and social gap which makes SEZs very exclusive areas; it also increases the chance for the backwash effect to occur (Thissen \& Van Oort, 2010; Urtasun \& Gutiérrez (2006). Cohen and Paul (2009) expound the effect of agglomeration is to increase the development of knowledge and skills, not only among companies but also between companies and the surrounding areas. This is possible only if the gap between the industry and the surrounding community is not too large. The transfer of knowledge is not possible if the industry with the latest vision and information is dealing with a community of low education level (Yang, 2016).

The large gap between the tourism SEZ investment strategy and the socio-economic conditions of the people in Mandalika region shows that in the context of tourism, agglomeration often does not occur based on market mechanisms. Instead, it is intervened through government policies. This is because, geographically, the tourist attractions are located in distant regions, which are economically unprofitable. Therefore, based on market mechanisms, it will be difficult for industries to gather to form clusters. Weber's theory in classical agglomeration is very influential in determining the location of a cluster, where companies will find the optimum point of distance to resources, markets, and labour centres (Cohen and Paul, 2009). On the other hand, in the context of tourism, clusters will be formed near the location of attraction, seemingly neglecting the distance to the centre of labour and the market (Liu et al, 2018: Yang, 2016). Consequently, the industry will try to overcome this problem of accessibility to attract markets, and labour migration will occur because the industrial location does not have workers who meet adequate or standard qualifications (Figure 2). To overcome this effect, the government should create a policy to reduce institutional barriers to labor mobility. It is also important to increase the supply of skilled labor through well-designed local vocational education and 
training and provide better access to higher education (Yang, 2016).

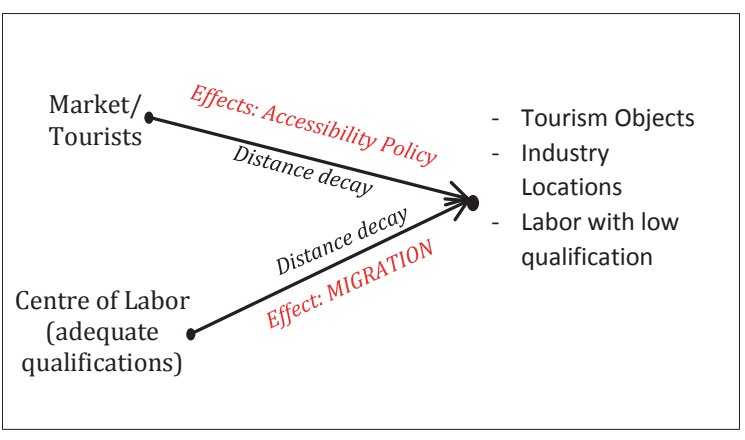

Figure 2. The Scheme of Tourism Agglomeration

In accordance with the regional development goals, the focus of development in the tourism sector is aimed at achieving community welfare. However, the performance of the tourism sector is only measured based on the target number of incoming foreign tourists. The number of tourists is then associated with the growth and occupancy rates of hotels and restaurants, as well as the size of tourist spending. Further observation reveals that the high growth of hotels and the amount of tourist spending do not necessarily indicate the welfare of local communities. This is possible because the hotel, restaurant, and other product industries are not based on local communities. Specific economic variables are not used as indicators to determine the effectiveness of the tourism sector's impact on people's welfare. The government unilaterally determines the targets and measures of tourism performance based on central interests, regardless of regional potential, constraints, and readiness, even though the basic objectives of national tourism development are among others to eradicate poverty and encourage economic growth (Nirwandar, 2006).

At the theoretical level, tourism is still rarely used as a subject to construct clustering theory in agglomeration. However, tourism is often used as an example of a clustering phenomenon (Liu et al, 2018; Thissen \& Van Oort, 2010; Urtasun \& Gutiérrez, 2006), although the tourism sector as an industry has different characteristics from other sectors. This research has mentioned the need to study the tourism phenomenon to enrich the theory of agglomeration in tourism.

\section{Conclusions}

Tourism agglomeration, especially in natural and cultural tourist areas that are geographically located in inaccessible areas, is not likely to occur if the government does not provide facilities in the forms of infrastructure development and other non-physical policies that facilitate affordability. The role of the government is vital to achieve economic efficiency and to attract industries to invest. However, the government should not focus solely on the ease of investment but also consider ways to involve the community in supporting the development in the region. The government also has the obligation to issue policies on the protection of existing natural resources from damage and on increasing people's welfare. The importance of collaboration shows the vital role of the government as a mediator and regulator. Accordingly, in particular, the roles of local governments are (1) developing a strategic plan for regional economic development, (2) building supporting infrastructure, such as airports, roads, theatre, and the like to facilitate the production process of tourism, and (3) connecting the public and private sectors.

The designation of tourism agglomeration areas in an attempt to accelerate regional economic development should be studied in-depth, taking into account regional readiness. A large gap between the centre of tourism agglomeration and the surrounding regions will have a negative effect, making it impossible to meet the goal of agglomeration to accelerate development and eradicate poverty.

Evenly distributed quality of human resources in accordance with the qualifications needed by the industry in the agglomeration area is the key to the success of a development. HR development and preparation policy should definitely be included as variables in tourism agglomeration. Government's support should not only focus on physical infrastructure but also on strengthening the quality of education. Existing industries must also seek support for the development of the quality of local human resources. Management of tourism agglomeration must be carried out with a sustainable approach by integrating tourism development strategies into regional development.

\section{Acknowledgment}

This work was supported by Indonesia Endowment Fund for Education (LPDP), as 
FITRI RAHMAFITRIA, et al. Agglomeration in Tourism: The Case of SEZs in Regional Development Goals...

the full-ride scholarship from the Indonesian Ministry of Finance, as a doctoral candidate at Bandung Institute of Technology.

\section{References}

Bank of Indonesia. (2014). Kajian Ekonomi Regional Provinsi Nusa Tenggara Barat. Triwulan II tahun 2014 (Nusa Tenggara Barat Province Regional Economic Studies: Second Quarter 2014). Kantor Perwakilan Bank Indonesia NTB. 114 hal.

Bank of Indonesia. (2018). Kajian Ekonomi Regional Provinsi Nusa Tenggara Barat. Triwulan II tahun 2014 ((Nusa Tenggara Barat Province Regional Economic Studies: Second Quarter 2014). Kantor Perwakilan Bank Indonesia NTB. 105 hal.

Benner, M. 2017. "From Clusters to Smart Specialization: Tourism in InstitutionSensitive Regional Development Policies." Economies 5: 1-20

Chiang, S. H. (2018). Assessing the Merits of the Urban-Led Policy in China: Spread or Backwash Effect?. Sustainability, 10(2), 451.

Cohen, J. P. \& Paul, C. J. M. (2009). Agglomeration, productivity and regional growth: production theory approaches. In: Capello, R \& Nijkamp P. Handbook of Regional Growth and Development Theories. Chapter 6. Edward Elgar. https:// www.mdpi.com/2071-1050/10/2/451

Fauzi, A., \& Oxtavianus, A. (2014). Pengukuran Pembangunan Berkelanjutan di Indonesia (Measuring Sustainable Development in Indonesia). MIMBAR, Jurnal Sosial dan Pembangunan, 30(1), 42-52. https:// ejournal.unisba.ac.id/index.php/mimbar/ article/view/445

Gunn, C. A., \& Var, T. (2002). Tourism planning: Basics, concepts, cases. Psychology Press.

Helmsing, B. (2001). Externalities, learning and governance: new perspectives on local economic development. Development and change, 32(2), 277-308. https://onlinelibrary.wiley.com/doi/ abs/10.1111/1467-7660.00206

Karlsson, C., \& Gråsjö, U. (2018). Knowledge flows, knowledge externalities, and regional economic development. Handbook of regional science, 1-28. https://link. springer.com/content/pdf/10.1007/9783-642-36203-3_25-1.pdf.

Kachniewska, M. (2013). Towards the definition of a tourism cluster. Journal of Entrepreneurship, Management and Innovation 9: 33-56. Available online: https://papers.ssrn.com/sol3/papers. cfm?abstract_id=2410446

Liu, J., Song, Q., Liu, N., \& Chi, C. G. (2018). Threshold effects of tourism agglomeration on the green innovation efficiency of China's tourism industry. Chinese Journal of Population Resources and Environment, 16(3), 277-286. https:// www.tandfonline.com/doi/abs/10.1080/ 10042857.2018.1502354

MacGillivray, A. (2017). Accounting for change: indicators for sustainable development. In Tomorrow's History (pp. 122-129). Routledge.

Marco-Lajara, B., Claver-Cortés, E., ÚbedaGarcía, M., \& del Carmen ZaragozaSáez, P. (2016). A dynamic analysis of the agglomeration and performance relationship. Journal of Business Research, 69(5), 1874-1879.

Martin P., \& Ottavianno. (2001). Growth and Agglomeration. International Economic Review 42(4), 947-968. https://onlinelibrary.wiley.com/doi/ abs/10.1111/1468-2354.00141

Nirwandar, S. (2006). Pembangunan Sektor Pariwisata di Era Otonomi Daerah (Tourism development in the era of regional autonomy). www.kemenpar.go.id

NTB dalam angka. (2017). Banyaknya Kunjungan Wisatawan ke Provinsi Nusa Tenggara Barat, 2009 - 2016. Dikutip dari www.bpsntb.go.id./2017/06/07

Parr, J. B. (2002). Missing Elements in the Analysis of Agglomeration Economies. International Regional Science Review, 25(2), 151-168. https://journals.sagepub.com/doi/ abs/10.1177/016001702762481221

Segarra-Oña, M. D. V., Miret-Pastor, L. G., Peiro-Signes, A., \& Verma, R. (2012). The effects of localization on economic performance: Analysis of Spanish tourism clusters. European Planning Studies, 20(8), 1319-1334.

Sodik, J., \& Iskandar, D. (2007). Aglomerasi dan pertumbuhan ekonomi: Peran karakteristik regional di Indonesia (Agglomeration and economic growth: The role of regional characteristics in Indonesia). Jurnal Ekonomi dan Studi Pembangunan Volume, 8(2), 117-129. https://aldinosuprima.blog. uns.ac.id/files/2010/05/agglomerasidan-pertumbuhan-ekonomi-perankarakteristik-regional-di-indonesia.pdf

Thissen, M., \& Van Oort, F. (2010). European place-based development policy and sustainable economic 
agglomeration. Tijdschrift voor economische en sociale geografie, 101(4), 473-480.

Tresiana, N., \& Duadji, N. (2018). Social Entrepreneur Model for Tourism Development in Kiluan Bay. MIMBAR, Jurnal Sosial dan Pembangunan, 34(1), 83-92. https://ejournal.unisba.ac.id/ index.php/mimbar/article/view/3141

Urtasun, A., \& Gutiérrez, I. (2006). Tourism agglomeration and its impact on social welfare: An empirical approach to the Spanish case. Tourism Management, 27(5), 901-912. https:// www.sciencedirect.com/science/article/ pii/S0261517705000543

Wildan, W., Sukardi, S., \& Syuaeb, M. Z. (2016). The feasibility of development of social capital-based ecotourism in
West Lombok. Mimbar: Jurnal Sosial dan Pembangunan, 32(1), 214-222. https:// www.neliti.com/publications/154228/ the-feasibility-of-development-of-socialcapital-based-ecotourism-in-west-lombok Yang, Y. (2016). Agglomeration density and labor productivity in china's tourism industry. International Journal of Tourism Research, 18(5), 434-446.

Yang, L., Shi, C. X., \& Zhong, P. J. (2018). Research on the Relationship between Tourism Industry Spatial Agglomeration and Regional Economic Development in Hunan Province. In Economic Forum (No. 9 , p. 14).

Yang, Y. (2016). Agglomeration density and labor productivity in china's tourism industry. International Journal of Tourism Research, 18 (5), 434-446. 